Dariusz Kasprzak ${ }^{1}$

Uniwersytet Papieski Jana Pawła II w Krakowie

\title{
Ubóstwo monastyczne a ubóstwo franciszkańskie - próba zestawienia tez normatywnych
}

W teologii duchowości istnieje ugruntowana teza, że każdy z fundatorów poszczególnych rodzin monastycznych i zakonnych miał własną wizję uwolnienia się od świata doczesnego, która była połączona z jego koncepcją dotyczącą własności instrumentów przydatnych do życia apostolskiego. Owe wizje i koncepcje odnoszące się do ubóstwa, które określamy jako dobrowolne, były uzależnione od kontekstu kulturowego, społeczno-ekonomicznego oraz cech osobowych każdego z fundatorów życia zakonnego. Od początku chrześcijaństwa nie istniała również jedność terminologiczna dotycząca ubóstwa dobrowolnego, dopiero od XII wieku tylko w teologii Kościoła zachodniego ubóstwo

Dariusz Kasprzak OFMCap, prof. nadzw. Uniwersytetu Papieskiego Jana Pawła II w Krakowie (od 2012), pracownik Katedry Patrologii UPJPII, dr hab. nauk teologicznych w zakresie patrologii, dr nauk patrystycznych (Augustinianum, Rzym 1999), autor trzech monografii i sześćdziesięciu artykułów naukowych z zakresu patrologii. Ostatnio wydał: Duszpasterze V wieku. Studium porównawcze myśli pasterskiej św. Piotra Chryzologa i Salwiana z Marsylii (Kraków 2008). Główne kierunki zainteresowań: Kościół patrystyczny, patrystyczna egzegeza i teologia biblijna, teologia patrystyczna, duchowość okresu patrystycznego. E-mail: kdario@poczta.onet.pl. 


\section{Dariusz Kasprzak}

jest jurydycznie opisywane jako jeden z trzech ślubów zakonnych, które następnie w okresie soboru watykańskiego II zostały zdefiniowane jako rady ewangeliczne. Jednak tak samo pojęcie, jak i koncepcja ubóstwa nie odgrywały takiej roli, jaką jej przypisała średniowieczna czy XX-wieczna tradycja kościelna - ani w Nowym Testamencie, ani w starożytności chrześcijańskiej, ani w Kościołach wschodnich. Brak jednoznacznych modeli ubóstwa dobrowolnego w Biblii i wczesnej tradycji Kościoła sprawił, że owe wzorce wykształciły się z czasem jako konstrukty ascetyczne.

Biorąc pod uwagę wymienione odrębności, pragnę w niniejszym artykule zestawić wiodące idee dotyczące ubóstwa dobrowolnego dla monastycyzmu okresu patrystycznego oraz dla zakonności franciszkańskiej. W badaniach będę się posługiwał metodą teologiczną, starając się systematyzować ideę ubóstwa dobrowolnego według kryterium hierarchii prawd wiary oraz metodę historyczną, szczególnie przy wykazywaniu kościelnego rozwoju tej idei oraz wskazaniu jej kontekstu historyczno-społecznego. Przedmiotem porównania będą najważniejsze tezy dotyczące ubóstwa dobrowolnego, jakie są zawarte w dokumentach normatywnych obu tradycji zakonnych, tj. w regułach zatwierdzonych (uznanych przez Kościół) oraz w duchowych tłumaczeniach norm zakonnych pochodzących z okresów charyzmatycznych obu tradycji zakonnych.

\section{1a. Przewodnia myśl biblijna o ubóstwie dobrowolnym w monastycyzmie - Dz 2, 44-45 i 2 Kor 8, 9}

Według nauczania Nowego Testamentu ubogimi byli ci, którzy pokornie podporządkowują się Bogu, zawierzają Mu w momencie wszelkich prób życiowych, otrzymują od Boga darmowe zbawienie i żyją we wspólnocie uczniów Zbawiciela² . Brak jednoznacznego modelu ewangeliczne-

2 Por. J. M. R. Tillard, Le propos de pauvreté et l'exigence évangélique, „Nouvelle Revue Theologique” 100 (1978), s. 207-232,359-372; S. Légasse, Richesse, [w:] Supplément au Dictionnaire 
go ubóstwa w pierwotnym Kościele stanowił przyczynę ukształtowania się w duchowości patrystycznej pięciu różnorodnych postaw ascetycznych wobec kwestii posiadania i posługiwania się dobrami materialny$\mathrm{mi}^{3}$. Od końca III wieku chrześcijański cenobityzm przejął jako własny jedynie piąty model, tj. formę ascetycznego wyrzeczenia się prawa do posiadania własności prywatnej, w celutworzenia chrześcijańskiej formy komunizmu społecznego. Forma ta powstała w oparciu o utopijną i charyzmatyczną wizję z Dz 2, 44-45 i 4, 32. Natomiast monastycyzm pierwotny, odwołując się do Dz 2, 44-45, mniej mówił o ubóstwie jako takim, natomiast bardziej podkreślał dystans do dóbr materialnych jako sposób indywidualnego życia bez własności indywidualnej ${ }^{4}$.

Pierwszym z ojców Kościoła odwołującym się do 2 Kor 8, 9 był Hilary z Poitiers (zm. 367), który wskazywał na fakt, że Chrystus stał się ubogim jako człowiek, aby ubogacić ludzi - darując im swoje zbawienie. Analogiczne odniesienia do 2 Kor 8,9 spotykamy w IV wieku tak-

de la Bible, fasc. 5-6, Paris 1982, k. 645-687; D. Kasprzak, Idea ubóstwa w Kościele pierwszych trzech wieków, „Analecta Cracoviensia” 42 (2010), s. 255-261.

Według klasyfikacji dokonanej przez Jeana Gribomonta, Povertà, [w:] Dizionario degli istituti di perfezione [dalej: DIP], t. 7, Roma 1983, k. 245 można wyróżnić w okresie patrystycznym następujące formy interpretacji ubóstwa ewangelicznego: 1) forma naturalisty c zne go, czasami wręcz c y nickiego odrzucenia dóbr cywilizacyjnych, przy próbach poprzestawania na tym, co natura sama ofiaruje; 2) forma żebrania w imię B o g a, duchowego powierzenia się Bogu i polegania na dobrodziejach, którzy dla zasług duchowych wspomagajążebrzącychwimię Boże; 3) for ma życia dzięki pracy apostolskiej przy dodatkowym, spontanicznym wsparciu ludzi, których się ewangelizowało; 4) forma pracy za wynagrodzeniem, połączona z apostolatem, jak to czynił apostoł Paweł; 5) forma ascetycznego wyrzeczenia się prawa do posiadania własności prywatnej w celu tworzenia chrześcijańskiej formy komunizmu społecznego.

4 Por. J. Gribomont, Povertà..., dz. cyt., k. 246-248. Jak podkreśla J. M. Lozano, The doctrine and practice of poverty in early monasticism, „Claretianum” nr 16 (1976), s. 5-32, pierwsi znani historycznie chrześcijańscy mnisi, jak Paweł z Teb (228-341) czy Antoni Wielki (250/251-356), postulowali dobrowolne opuszczenie własności prywatnej, wycofanie się na pustynię oraz ograniczenie do minimum własnych potrzeb materialnych. Niewątpliwie pierwsi anachoreci chrześcijańscy posiadali ograniczoną własność prywatną, podstawą ich utrzymania była praca rąk własnych, natomiast troska o chorych i starych mnichów wymuszała posiadanie wymiernych środków materialnych. 
że u późniejszych teologów (Efrema Syryjczyka, Bazylego Wielkiego, Ambrożego z Mediolanu czy Augustyna z Hippony). W teologii chrześcijańskiej do IV wieku włącznie ojcowie i pisarze Kościoła mówili o dwóch wymiarach ubóstwa Jezusa Chrystusa: ubóstwie natury i ubóstwie faktycznym. Najważniejsze było to pierwsze, rozumiane jako wcielenie - uczłowieczenie Drugiej Osoby Bożej. Ubóstwo faktyczne Jezusa było jedynie prostym znakiem, ujawniającym przed ludźmi uniżenie Wcielonego Boga ${ }^{5}$.

\section{1b. Przewodnia myśl biblijna o ubóstwie dobrowolnym u Franciszka z Asyżu - 2 Kor 8, 9}

W tekstach Franciszka z Asyżu brak jasno określonej definicji ubóstwa dobrowolnego. Lázaro Iriarte zauważył, iż Franciszek jako charyzmatyk bardziej opisywał własne doświadczenia duchowe, niż definiował ewangeliczne postawy zachowania ${ }^{6}$. Drogą Franciszka do dobrowolnego ubóstwa była jego osobista lektura Ewangelii, szczególnie Mt 10, 7-19; 16, 24; 19, 21; Łk 9, 3. 237. Podstawowym wymiarem ubóstwa dobrowolnego była dla Franciszka postawa „ubóstwa i pokory naszego Pana Jezusa Chrystusa” (,paupertate et humilitate Domini nostri Jesu Christi”), która miała znaleźć odzwierciedlenie w życiu Braci Mniejszych ${ }^{8}$. Analogiczne

5 Por. D. Kasprzak, Idea ubóstwa w Kościele pierwszych trzech wieków..., dz. cyt., 262-268.

6 Por. L. Iriarte, Powołanie franciszkańskie. Synteza ideałów św. Franciszka iśw. Klary, przekł. S. Kafel, Kraków 1999, s. 147.

7 Por. L. Hardick, Ubóstwo, [w:] Leksykon duchowości franciszkańskiej, wyd. pol. - przekł. i oprac. zbiorowe, Kraków 2006, s. 1866.

8 Por. Franciscus Assisiensis, Regula non bullata 9, 1: „Omnes fratres studeant sequi humilitatem et paupertatem Domini nostri Jesu Christi”, [w:] Święci Franciszeki Klara, Pisma, wyd.łac.-pol. [dalej: Pisma FK], tekst łaciński: Fontes Franciscani, przekł. K. Ambrożkiewicz, Kraków-Warszawa 2002, s. 150; Franciscus Assisiensis, Regula bullata 6, 3: „[Fratres] Et tanquam peregrini et advenae in hoc saeculo in paupertate et humilitate Domino famulantes vadant pro eleemosyna confidenter", Pisma FK, s. 184, por. 1 P 2, 11; Franciscus Assisiensis, Regula bullata 12, 5: ,ut semper subditi et subiecti pedibus eiusdem sanctae Ecclesiae stabiles in fide catholica paupertatem et humilitatem et sanctum evangelium Domini nostri Jesu Christi, quod firmiter promisimus, observemus", Pisma FK, s. 190, por. Kol 1, 23; Franciscus 
wyrażenia znajdujemy w tekstach Klary z Asyżu', natomiast zasadniczo brak owego dwumianu u pierwszych hagiografów franciszkańskich ${ }^{10}$.

W Franciszkowym, intuicyjnym odczytaniu Nowego Testamentu ubóstwo dobrowolne jest owocem miłości - tajemnicą obecności Chrystusa w człowieku ubogim, Chrystusa, który objawia się w każdym, kto upodabnia się do niego. Stąd Franciszek przekazuje ascetykę ubóstwa w duchu, która jest stabilizowana na podstawach braterstwa i małości, co uwidacznia się już w samej nazwie zakonu: Bracia Mniejsi (Ordo Fratrum Minorum $)^{11}$. W tekstach Franciszka takie odczytanie kenozy Chrystusa

Assisiensis, Salutatio virtutum 2: „Domina sancta paupertas, Dominus te salvet cum tua sorore sancta humilitate", Pisma FK, s. 276.

$9 \quad$ Por. Clara Assisiensis, Regula 8, 1-2: „1. Sorores nihil sibi approprient, nec domum nec locum, nec aliquam rem, 2. et tanquam peregrinae et advenae in hoc saeculo, in paupertate et humilitate Domino famulantes, mittant pro elemosyna confidenter", Pisma FK, s. 474, por. 1 P 2, 11; Clara Assisiensis, Regula 12, 13: „paupertatem et humilitatem Domini nostri Iesu Christi... in perpetuum observemus", Pisma FK, 484; Clara Assisiensis, Testamentum 46: „insequendo paupertatem et humilitatem dilecti Filii sui”, Pisma FK, s. 490; Clara Assisiensis, Testamentum 56: „ut semper studeant imitari viam sanctae simplicitatis, humilitatis, paupertatis", Pisma FK, s. 492; Clara Assisiensis, [2] Epistola ad sanctam Agnetem de Praga 7: ,aemula sanctissimae paupertatis effecta in spiritu humilitatis”, Pisma FK, s. 504; Clara Assisiensis, [3] Epistola ad sanctam Agnetem de Praga 4: „pauperis et humilis Iesu Christi", Pisma FK, s. 508; Clara Assisiensis, [3] Epistola ad sanctam Agnetem de Praga 7: „humilitate, virtute fidei ac paupertatis brachiis amplexari”, Pisma FK, s. 508; Clara Assisiensis, [3] Epistola ad sanctam Agnetem de Praga 25: „humilitatis praesertim et paupertatis”, Pisma FK, s. 510; Clara Assisiensis, [4] Epistola ad sanctam Agnetem de Praga 18: „beata paupertas, sancta humilitas", Pisma FK, s. 516; Clara Assisiensis, [4] Epistola ad sanctam Agnetem de Praga 22: „humilitatem, saltem beatam paupertatem”, Pisma FK, s. 516; Clara Assisiensis, Epistola ad Ermentrudem 14: „in paupertate sancta et humilitate sincera adimple", Pisma FK, s. 520.

10 Zdaniem L. Iriarte, Powołanie franciszkańskie..., dz.cyt., s. 147, ów brak wskazuje na ewidentną zmianę narracji o Franciszku i jego ubóstwie przez XIII- i XIV-wiecznych biografów czy autorów dzieł ascetycznych.

11 Por. L. Iriarte, Powołanie franciszkańskie..., dz.cyt., s. 166-168; por. Franciscus Assisiensis, Regula non bullata 2, 11; 7, 2: Pisma FK, s. 138; 146; Franciscus Assisiensis, Regula bullata 1, 2; 2, 8.11.17; 3, 12; 7, 3; 10, 8-13: Pisma FK, s. 178; 180; 182; 186; 188.190; Franciscus Assisiensis, Testamentum 19: Pisma FK, s. 216; Franciscus Assisiensis, Salutatio virtutum 10-12: Pisma FK, s. 276; Thomae de Celano, Vita secunda sancti Francisci 148, [w:] Fontes Franciscani, 2: Testi [dalej: FF 2], a cura di E. Manestò, S. Brufani, Assisi 1995, s. 574-575. 
posiada biblijne odniesienie do 2 Kor $8,9^{12}$. Szczególnie przeżywanymi przez Franciszka tajemnicami Chrystusowego uniżenia-pokory były: wcielenie Syna Bożego, Jego ukrzyżowanie oraz Eucharystia, ukazujące tajemnicę wejścia Boga w ludzkie życie właśnie poprzez realną biedę (por. Tomasz z Celano, Vita secunda 83; 200), fizyczne wyniszczenie (por. Tomasz z Celano, Vita prima 71) i codzienne przyjście do wierzących w pokornej postaci (por. Franciszek z Asyżu, Napomnienie 1, 16-17)13. Stąd Franciszkowe zalecenie dla jego braci, aby byli zarówno mniejsi: „niech każdy raczej siebie samego sądzi i sobą gardzi”"14, jak i pokorni: „Błogosławiony sługa, który nie uważa się za lepszego, gdy go ludzie chwalą i wywyższają niż wówczas, gdy go uważają za słabego, prostego i godnego pogardy..."15. Według Franciszka swoistą sztuką Braci Mniejszych jest ich posłannictwo małości dzięki „przechodzeniu niezauważonymi przez ten świat” - bycie jako zaczyn ewangeliczny w świecie, tym skuteczniejszy, im mniej związany z tym światem: „O, gdyby to być mogło, a było po mojej myśli, żeby świat bardzo rzadko widywał Braci Mniejszych i dziwił się ich małej liczbie"16.

12 Por. Franciscus Assisiensis, Regula bullata 6, 4: „nec oportet eos verecundari, quia Dominus pro nobis se fecit pauperem in hoc mundo”, Pisma FK, s. 184; Franciscus Assisiensis, Epistola ad Fideles (recensio posterior) 4-5: „4. Istud Verbum Patris tam dignum, tam sanctum et gloriosum nuntiavit altissimus Pater de caelo per sanctum Gabrielem angelum suum in uterum sanctae et gloriosae virginis Mariae, ex cuius utero veram recepit carnem humanitatis et fragilitatis nostrae. 5. Qui, cum dives esset super omnia, voluit ipse in mundo cum beatissima Virgine, matre sua, eligere paupertatem", Pisma FK, s. 232. Zobacz też: Thomae de Celano, Vita secunda sancti Francisci 74: „[Franciscus dixit:] «Carissimi fratres, Dei Filius nobilior nobis erat, qui 'pro nobis se fecit pauperem in hoc mundo'. Suo amore viam paupertatis elegimus; non debemus confundi pro eleemosynis ire»”, FF 2, s. 512.

13 Por. L. Iriarte, Powołanie franciszkańskie..., s. 148-150; L. Hardick, Ubóstwo..., dz. cyt., s. 1887-1889 (ten ostatni badacz podkreśla, iż koncepcja ubóstwa dobrowolnego u Franciszka nie odwołuje się do życia wspólnoty jerozolimskiej, ale do przykładu życia Jezusa).

14 Franciscus Assisiensis, Regula bullata 2, 18: Pisma FK, s. 180. 181.

15 Franciscus Assisiensis, Admonitiones 19: Pisma FK, s. 126-129.

${ }_{16}$ Thomae de Celano, Vita secunda sancti Francisci 70, FF, s. 509 (tłum. polskie: Brat Tomasz z Celano, Życiorys drugi św. Franciszka z Asyżu, [w:] Źródła franciszkańskie. Pisma świętego Franciszka. Źródła biograficzne świętego Franciszka. Pisma świętej Klary i źródła biograficzne. Teksty ustalające normy dla braci i sióstr od pokuty [dalej: ŹF], przekł. C. T. Niezgoda, Kraków 2005, s. 614). 


\section{2a. Wyrzeczenie się prawa własności normą cenobityzmu chrześcijańskiego}

Analizując najbardziej reprezentatywne reguły pierwotnego cenobityzmu chrześcijańskiego, to jest: Regułę św. Pachomiusza ${ }^{17}$, Reguły dłuższe i reguły krótsześw. Bazylego Wielkiego ${ }^{18}$, Praeceptum św. Augustyna z Hippony ${ }^{19}$, Regułę Czterech Ojców ${ }^{20}$, Regułę Mistrza ${ }^{21}$ oraz Regułęśw. Benedykta ${ }^{22}$, doszedłem już kiedyś do wniosku, iż wyrzeczenie się prawa do własności prywatnej stanowiło najważniejszy etap stanu separacji podczas inicja-

17 Oryginał koptyjski tej pierwszej reguły cenobickiej pochodzi sprzed 347 roku i zachował się w jednej trzeciej, a tłumaczenie greckie istnieje dziś jedynie w połowie. Obecnie posiadamy kompletny jedynie łaciński przekład Hieronima ze Strydonu z 404 r.; Fragmenty koptyjskie Reguły Pachomiusza: Fragmenty koptyjskie Reguły Pachomiusza, Oeuvres de s. Pachôme et de ses disciplesed, ed. T. L. Lefort, Louvain 1956, s. 30-36 (Corpus Scriptorum Christianorum Orientalium 159/Copt. 23); ed. H. Bacht, „Muséon” nr 75 (1962), s. 5-18; Fragment greckie Reguły Pachomiusza, red. T. L. Lefort, „Muséon” nr 37 (1924), s. 1-28; Pachomiana latina, ed. A. Boon, Louvain 1932, s. 169-182. S. Eusebii Hieronymi Stridonensis Presbyteri, Translatio Latina Regulae Sancti Pachomii, Patrologia Latina, 23, ed. J. P. Migne, Paris 1883, k. 65-92; przekł. pol. Św. Hieronim ze Strydonu, Reguła św. Pachomiusza, [w:] Pachomiana Latina, przekł. A. Bober, Kraków 1996, s. 123-172 (Źródła Monastyczne, 11).

18 Tzw. Wielki Asketikon, napisany ok. 377 roku: S. Basilius Magnus, Caesariensis Archiepiscopus, Regulae fusius tractatae: Patrologia Graeca, 31, ed. J. P. Migne, Paris 1857, k. 889-1052; przekład polski: Św. Bazyli Wielki. Pisma ascetyczne, t. 2. Reguły dłuższe. Reguły krótsze, przekł. J. Naumowicz, Kraków 1995 (Źródła Monastyczne, 6).

19 Tekst z 397 roku: S. Augustinus, Hipponensis Episcopus, Regula ad servos Dei, a cura di L. Verheijen, Roma 2001, s. 30-48 (Nuova Biblioteka Agostiniana [dalej: NBA], 7/2), przekł. pol.: Św. Augustyn, Reguła, [w:] Św. Augustyn, Pisma monastyczne, przekł. P. Nehring, Kraków 2002, s. 151-168 (Źródła Monastyczne, 27).

20 Napisana w Lerynie pomiędzy 400 a 410:Regula Sanctorum Serapionis, Macarii, Paphnutii et Alterius Macarii: MPL 103, k. 435-442; przekład polski: Reguła świętych ojców Serapiona, Makarego, Pafnucego i Makarego Drugiego (Reguła Czterech Ojców), [w:] Wczesne reguły monastyczne z Galii, przekł. K. Bielawski, Kraków 2007², s. 41-53 (Źródła Monastyczne, 3).

${ }_{21}$ Powstała przed 530 rokiem: La Règle du Maître, red. A. de Vogüé, Paris 1964 (Sources Chrétiennes, 105-106); przekład polski: Reguła Mistrza, [w:] Reguła Mistrza. Reguła św. Benedykta, tłum. pol. T. M. Dąbek, Kraków 2006, s. 67-371 (Źródła Monastyczne, 40).

22 Napisanaw okresie pomiędzy 530 a 555 rokiem: La Règle de Saint Benoît, red. A. de Vogüé, Paris 1971-1972 (Sources Chrétiennes, 181-186); przekł. pol. Reguła św. Benedykta, [w:] Reguła Mistrza. Reguła św. Benedykta, przekł. B. Turowicz, Kraków 2006, s. 387-503 (Źródła Monastyczne, 40). 


\section{Dariusz Kasprzak}

cji do życia monastycznego ${ }^{23}$. Rytowi zewnętrznego wyrzeczenia miała towarzyszyć wewnętrzna wolność przejawiająca się brakiem jakiegokolwiek przywiązania do dóbr materialnych oraz relacji międzyludzkich. Motywy takiego wyrzeczenia były różne: całkowite zapomnienie o wszystkim, co było, i rezygnacja z własnych zachcianek (Reguła Bazylego), wspólnota umysłów i serc, która miała czynić mnicha dyspozycyjnym wobec Boga (Reguła Augustyna), środek zabezpieczający wytrwanie mnicha w zakonie (Reguła Mistrza), wyrzeczenie się świata i własnej woli, będące wyrazem wiarygodności samego powołania (Reguła Pachomiusza, Reguła Czterech Ojców, Reguła Benedykta). Wyrzeczenie się własności następowało przez sprzedaż dóbr i rozdanie nabytych tym sposobem pieniędzy ubogim lub donację na rzecz monasteru. Od momentu przyrzeczenia rezygnacja z własności indywidualnej miała obowiązywać mnicha przez całe jego dalsze życie ${ }^{24}$.

\section{2b. Nieposiadanie niczego na własność normą ubóstwa Franciszka z Asyżu}

Dla Franciszka jedynym dobrem godnym pragnienia jest Bóg, natomiast wszelkie pozostałe dobra należy odnosić do Boga, uznając je za Jego własność ${ }^{25}$. Jak podkreśla Iriarte, opis teologii prawa własności został dokonany przez Franciszka przy użyciu pojęć feudalnych ${ }^{26}$. Bóg jest królem uniwersalnym; dobra ziemskie są przez Niego przydzielane jako czasowe lenno (in feudo); człowiek jest wasalem Boga, w którego ręce dobrowolnie (tj. za życia) lub z konieczności (tj. po śmierci) składa wszystko, co

${ }_{23}$ Por. D. Kasprzak, Obrzędy przejścia podczas inicjacji monastycznej w starożytnych regułach zakonnych, [w:] Katechumenat i inicjacja chrześcijańska w Kościele starożytnym, red. P. Szczur, Lublin 2011, s. 147-151.

24 Por. D. Kasprzak, Obrzędy przejścia podczas inicjacji monastycznej..., dz.cyt., s. 150-151.

25 Por. Franciscus Assisiensis, Regula non bullata 23, 8-11; 17,7: Pisma FK, s. 174; 160; zobacz też L. Hardick, Ubóstwo..., dz. cyt., s. 1893-1894.

26 Por. L. Iriarte, „Appropriatio” et ,expropriatio” in doctrina sanncti Francisci, „Laurentianum” nr 11 (1970), s. 3-35. 
posiada; grzech jest przywłaszczeniem sobie własności (feudum) ${ }^{27}$. Stąd zapis w Regule zatwierdzonej „Fratres nihil sibi approprient (Bracia niech niczego nie nabywają na własność)" ${ }^{28}$ oznaczał według Franciszka dobrowolny akt wywłaszczenia z dóbr zewnętrznych i wewnętrznych, traktowany jako oddanie dóbr własnych Bogu ${ }^{29}$.

\section{3a. Chrześcijanin wygnańcem na tym świecie - idea całej tradycji Kościoła}

Przesłanie chrześcijańskie od samego początku głosiło, iż wierzący są w tym świecie jako obcy i przybysze (1 P 2,11-17), gdyż są nie z tego świata (por. J 17, 11-16), a ich prawdziwą ojczyzną jest niebo, skąd oczekują przyjścia Zbawiciela, Jezusa Chrystusa (por. Flp 3, 20). Doczesność to dla chrześcijan czas próby i pielgrzymowania do przyszłej, prawdziwej ojczyzny (por. 1 P 1, 17; Hbr 13, 14) ${ }^{30}$. Dlatego od powstania życia monastycznego w Kościele tak anachoreci, jak i cenobici uznawali tę formę

27 Por. Franciscus Assisiensis, Admonitiones 18, 2: Pisma FK, s. 126; Franciscus Assisiensis, Epistola ad Fideles (Recensio posterior) 31; 70: Pisma FK, s. 234; 240.

28 Por. Franciscus Assisiensis, Regula bullata 6, 2: Pisma FK, s. 184; Franciscus Assisiensis, Testamentum 24: Pisma FK, s. 216; Franciscus Assisiensis, Admonitiones 28: Pisma FK 132; L. Iriarte, El rito de la profesión en la Orden franciscana. Apuntes históricos, „Laurentianum” 8 (1967), s. 190-193.

29 L. Iriarte, Powołanie franciszkańskie..., dz. cyt., s. 158-159 wykazuje, że miało to doprowadzić Braci Mniejszych do postawy serca oderwanego od wszelkich dóbr (indywidualnych czy wspólnotowych) - tzw. „serca ubogiego” i bycia dyspozycyjnymi dla Boga i ludzi. Takie ujęcie ubóstwa to przede wszystkim przykład życia samego Jezusa. Natomiast w perspektywie średniowiecznej nauka Franciszka została ukształtowana pod wpływem antyprzykładu dawanego przez komuny miejskie Italii, współzawodniczące ze sobą w zdobywaniu władzy i zaspokajaniu miejskiej pychy, wynikającej z bogactwa handlowego. Stąd Franciszkowe zalecenie, aby jego bracia - tak indywidualnie, jak wspólnotowo - nie posiadali niczego na własność, czyli niczego sobie nie przywłaszczali, wtedy będą mniejszymi. o historii określenia „sine proprio” oraz o kościelnym powrocie do Franciszkowego wykładu nauki o przywłaszczeniu (tj. o odczytaniu tekstu Reguły według znaczenia, jakie mu nadal założyciel Braci Mniejszych) mocą dekretu Kongregacji dla zakonników z 4 marca 1970, zob. L. Iriarte, La povertà nelle interpretazioni papali antiche e le conseguenze del recente decreto abrogativo delle medesime, „Studi e Ricerche Francescane” 9 (1980), s. 79-97.

30 Por. F. Raurell, Itineranti alle origini, itinerantinel tempo: una visione biblica, [w:] Peregrini e forestieri. L'itineranza francescana, a cura di L. Padovese, Bologna 2004, s. 21-41; S. Légasse, 


\section{Dariusz Kasprzak}

naśladowania Chrystusa za rodzaj wygnania czy pielgrzymowania przez doczesność, gdyż właściwą ojczyzną mnicha jest tylko niebo ${ }^{31}$. To dziedzictwo monastycyzmu antycznego podjęli mnisi średniowieczni, którzy zgodnie z pierwotną tradycją chrześcijańską zarówno uosabiali i ukazywali pielgrzymujący charakter Kościoła, jak i odzwierciedlali jego eschatologiczne nastawienie ${ }^{32}$.

\section{3b. Bycie obcym i pielgrzymem na tym świecie - idea Franciszka z Asyżu}

Doktryna o ubóstwie jest w pismach Franciszka przesiąknięta motywacją eschatologiczną ${ }^{33}$. Brat mniejszy, naśladując Chrystusa ubogiego i nieposiadającego domu, jako pielgrzym na ziemi winien dążyć do nieba, a doczesność traktować jako przejściowy okres próby (por. Tomasz z Celano, Życiorys Drugi 56). Dlatego nie powinien przywiązywać się do czegokolwiek w doczesności, powinien zachowywać postawę prowizoryczności w odniesieniu do środków utrzymania i zamieszkania (por. Franciszek z Asyżu, Testament 24), nie osiedlać się na stałe na tej ziemi, ale stale oczekiwać na przyjście dnia Pańskiego (por. Tomasz z Celano, Życiorys Drugi 156). Duży wpływ na kształtowanie się Franciszkowej postawy pielgrzyma w doczesności odegrała obok wskazań Ewangelii rozwinięta w średniowieczu idea pielgrzymowania, przypominająca wierzącym ich stan wędrowców ku wieczności, oraz sama idea życia zakonnego, obrazująca Kościół pielgrzymujący ku wieczności ${ }^{34}$.

L'itineranza di Gesú e dei suoi discepoli. Storia e vangeli, [w:] Peregrini e forestieri. L'itineranza francescana, a cura di L. Padovese, Bologna 2004, s. 43-55.

31 Por. B. Kötting, Peregrinatio religiosa. Wallfahrten in der Antike und das pilgerwesen in der alten Kirche, Münster 1950; M. Dietz, Wandering monks, virgins, and pilgrims ascetic travel in the Mediterranean world, A.D. 300-800, University Park 2005, szczególnie s. 69-106 i 155-188.

32 Por. J. Leclerq, U źródet duchowości Zachodu. Etapy rozwoju i elementy stałe, przekł. Sz. Sztuka, Kraków 2009, s. 47-111.

33 Por. Franciscus Assisiensis, Regula non bullata 1, 5: Pisma FK, s. 136; Franciscus Assisiensis, Regula bullata 6, 3-7: Pisma FK, s. 184.

34 Por. L. Iriarte, Powołanie franciszkańskie..., dz. cyt., s. 159-162. 


\section{4a. Pieniądz deprawuje mnicha - zalecenie powstrzymywania się od posiadania pieniędzy}

Już w Regule Pachomiusza spotykamy pierwszy zakaz posiadania pieniędzy przez cenobitów ${ }^{35}$. Analogiczne w swej treści rozporządzenia spotykamy w Księdze Horsiesiego ${ }^{36}$, u Sulpicjusza Sewera, Vita Martini 4; 10, 6; u Hieronima, Epistula 57, 2 czy u Augustyna z Hippony, De moribus II, 74. Było to jednak wezwanie do pewnego ideału, gdyż pieniądze zawsze były w użyciu w większości opisywanych monasterów, a wyjątkiem byli ci mnisi, którzy z nich realnie zrezygnowali. Mnisi posiadali pieniądze jako wspólnota skutkiem prowadzonej przez nich działalności gospodarczej oraz dzięki donacjom wiernych. Pieniądze gromadzone przez wspólnotę były oddawane do podziału: miały służyć zaspokojeniu potrzeb mnichów i racjonalnej gospodarce monasterem, finansowano z nich podróże do innych monasterów, aby zakładać nowe fundacje; pomagano więźniom, utrzymywano przytułki dla chorych czy podróżnych. Niedozwolone było natomiast prywatne bogacenie się mnichów. Pomimo zakazów antyczni mnisi zarabiali pieniądze indywidualnie przez podejmowanie prac w tajemnicy przed przełożonymi, przez zakładanie małych posiadłości na wsiach, przez uprawę prywatnych winnic czy ogrodów warzywnych. Sumy gromadzone indywidualnie przez mnichów były raczej niewielkie, nie zmieniało to jednak faktu, że według ascetyki monastycznej jakikolwiek pieniądz (nummus czy denar) mógł duchowo zdeprawować mnicha, gdyż wzbudzał żądzę, chciwośćc ${ }^{37}$.

35 Pachomiusz, Reguła - Przykazania 81: „Nikomu nie wolno mieć w domu i w swojej celi czegokolwiek, prócz tych rzeczy, jakie przewiduje powszechne prawo klasztorne; ani tuniki lnianiej [...] ani drobnych pieniędzy", Pachomiana Latina, dz. cyt., s. 145.

${ }_{36}$ Księga Horsiesiego 22: „Jeśli ktoś, komu powierzono jakąś służbę lub zarząd klasztoru, ciągnąłby z tego zysk dla siebie i cokolwiek z tego brałby na własny pożytek, niech to będzie uważane za zbrodnię i świętokradztwo", Pachomiana Latina, dz.cyt., s. 233; Księga Horsiesiego 27. Nie zachowywać własności aż do śmierci, Pachomiana Latina, dz. cyt., s. 239-241.

37 Por. J. Jundziłł, Pieniądz w łacińskiej literaturze chrześcijańskiej późnego cesarstwa rzymskiego, Warszawa 1984, s. 135-137 (Studia Antiquitatis Christianae, 3); J. Jundziłł, Złoto i srebro jako pieniądz w łacińskiej literaturze patrystycznej okresu późnego cesarstwa rzymskiego, „Vox Patrum" 7 (1987) 12-13, s. 189-205; I. Milewski, Pieniądz w greckiej literaturze patrystycznej IV wieku, Gdańsk 1999, s. 91-92. 


\section{4b. Zakaz przyjmowania pieniędzy}

Zakaz przyjmowania pieniędzy z Reguły zatwierdzonej 4 jest ascetycznie umotywowany chęcią zapobieżenia chciwości i pogoni za dobrami świata doczesnego. Franciszek nie mówi o zakazie używania pieniędzy czy też o zakazie ich dotykania, gdyż są to opowiadania ascetyczne powstałe jako późniejsze interpretacje reguły ${ }^{38}$. Z czasem franciszkańskie spory interpretacyjne skupiły się nad prawniczym znaczeniem litery, tak jakby chodziło o materialne nieprzyjmowanie pieniędzy. Dzięki kolejnym papieskim interpretacjom reguły znaleziono jurydycznie sposób by w zakonie mieć pieniądze i rozporządzać nimi bez ich formalnego przyjmowania. Natomiast sam Franciszek wyraża pragnienie: „ut nullo modo denarios vel pecuniam recipiant (aby nie przyjmowali pieniędzy) ${ }^{39}$ ". Podobnie Klara wolała być wierna duchowi Reguły Franciszka, dostrzegając niemożliwość wierności literze prawa. Stąd nie tylko nie wspomina o czwartym rozdziale reguły Braci Mniejszych, ale - co więcej - przyjmuje za normalne posługiwanie się pieniędzmi przez siostry, jednak tak, by były one ubogie także wtedy, gdy mają pieniądze ${ }^{40}$.

38 L. Iriarte, Powołanie franciszkańskie..., dz.cyt., s. 164 zauważa, iż Franciszkowy zakaz przyjmowania pieniędzy potęgowały u Franciszka osobiste wspomnienia: pozytywnie doświadczenie odbudowy kościółka San Damiano bez środków własnych, ale także negatywne - przykłady żądzy pieniędzy u własnego ojca Piotra Bernardone (będące pośrednio przyczyną niezgody między nimi), przykłady konformistycznego zabezpieczenia ekonomicznego charakteryzującego czy to XIII-wiecznych kupców, czy wędrownych zakonników i kaznodziejów, oraz symbolika pieniądza jako wyrazu siły politycznej komun miejskich XIII-wiecznej Italii. Natomiast wspomniane opowiadania hagiograficzne o zakazie używania pieniędzy czy też o zakazie ich dotykania są echem pewnej nadbudowy ascetycznej, powstałej później w zakonie jako skutek problemów związanych z używaniem pieniędzy i przerzuconych później na założyciela.

39 Franciscus Assisiensis, Regula bullata 4, 2: Pisma FK, s. 182; por. Franciscus Assisiensis, Regula non bullata 8,3: „nec recipiat nec recipi faciat pecuniam aut denarios”, Pisma FK, s. 148 .

40 Por. L. Iriarte, Powotanie franciszkańskie..., dz. cyt., s. 163-165; por. por. Clara Assisiensis, Regula 8, 11: „Si vero ei aliqua pecunia transmissa fuerit, abbatissa de consilio discretarum in hiis quae indiget illi faciat provideri”, Pisma FK, s. 476. 


\section{5a. Praca - biblijny obowiązek i życiowa konieczność mnicha}

Praca jako obowiązek człowieka wynika z objawienia biblijnego (por. Rdz 2, 15; Wj 20, 9; Mk 6, 3; Mt 10, 10; 24, 45-51; 2 Tes 3, 10-12; etc.). Egipscy eremici pracowali przede wszystkim, aby zapewnić sobie pożywienie i utrzymanie. Anachoreci najczęściej pracowali samotnie w swych celach, zajmując się wyplataniem koszy z trzcin i młodych pędów palm. Eremici ze Sketis i Nitrii brali też udział w żniwach, za co otrzymywali zapłatę w zbożu. Nie byli więc żebrakami, jak syryjscy „doskonali”, znani z Księgi stopni, czy messalianie, którzy nie uznawali obowiązku pracy, lecz uważali ją za coś złego i obrzydliwego ${ }^{41}$. Obowiązek pracy spotykamy także w dokumentach normatywnych dla cenobitów Pachomiusza ${ }^{42}$ i Horsiesiego ${ }^{43}$. Praca mnichów egipskich, głównie ręczna, miała jednak swoje wyraźne granice: mimo że obowiązkowa, była ona jednak działalnością drugorzędną w stosunku do wewnętrznego spokoju i poszukiwania Boga, nie powinna razić innych, nie powinna też wbijać mnicha w pychę ${ }^{44}$. Praca była zatem Bożą instytucją przewidzianą dla człowieka w akcie stworzenia; jest też Bożym przykazaniem; poprzez którego realizację człowiek na swój sposób kontynuuje dzieło Bożego stwarzania; zapewnia sobie i swoim bliskim środki do życia. Dlatego mnich, jak każdy inny chrześcijanin, nie może unikać obowiązku pracy (por. Augustyn, De opere monachorum 1, 2; 16, 9) ${ }^{45}$.

${ }^{41}$ Por. A. Guillaumont, U źródeł monastycyzmu chrześcijańskiego, t. 1, przekł. S. Wirpszanka, Kraków 2006, s. 162-168 (Źródła Monastyczne, 37).

${ }^{42}$ Pachomiusz, Przykazanie 5. „Nie siedź bezczynnie na zgromadzeniu [modlitewnym], lecz szybką pracą rąk przygotuj osnowy i wątki na maty. Zwolnieni są tylko słabi fizycznie i tym pozwala się nie brać udziału w tej pracy",Pachomiana Latina, dz. cyt., s. 129; Pachomiusz, List 3, 11: „Teraz jest czas, abyśmy pracowali dla pana, albowiem nasze zbawienie jest w czasie ucisku", Pachomiana Latina, dz.cyt., s. 184; por. też: Pachomiusz, Przykazanie 23; 24; 27; 58-67; 123; 124; Pachomiusz, Przykazania i postanowienia 3-5; Pachomiusz, Przykazania i orzeczenia 5; Przykazania i prawa 1; 3.

43 Por. Księga Horsiesiego 7; 9; 17; 22; 30; 49: Pachomiana Latina, dz.cyt., s. 215-216; $217-$ 218; 225-227; 233-234; 243-244; 262-263.

${ }_{44}$ Por. E. Wipszycka, Drugi dar Nilu czyli o mnichach i klasztorach w późnoantycznym Egipcie, Kraków 2014, s. 397-398.

45 Por. A. Quacquarelli, L'educazione al lavoro. Dall'antica comunità cristiana al monacesimo primitivo, [w:] Res cristiana: temi interdisciplinari do patrologia, a cura di A. Quacquarelli, Roma 1992, s. 9-22. 


\section{5b. Praca i jałmużna}

W Regule zatwierdzonej Franciszek nazywa pracę łaską ${ }^{46}$. Jej motywacja jest klasycznie ascetyczna, tj. unikanie lenistwa, sama zaś praca nie powinna stanowić niebezpieczeństwa dla ducha modlitwy i pobożności. Taka praca jest środkiem utrzymania dla braci i jest wykonywana poza zakonem. Franciszek doceniał pracę tak fizyczną ${ }^{47}$, jak intelektualną ${ }^{48}$. Pracę braci przyrównywał do tej wykonywanej przez pszczoły (laborem apum), a braci leniwych i stroniących od pracy - do trutni (similis es fratrii aponi) i much (frater musca) ${ }^{49}$, bezczynność tych ostatnich zdecydowanie gani ${ }^{50}$. W Regule zatwierdzonej 5 nie ma już rozróżnienia na braci pracujących i tych, którzy nie mają żadnego zawodu, nie istnieje też w regule zatwierdzonej swoista preferencja pracy ręcznej, jaka istniała w Regule niezatwierdzonej 8. Charakter samej pracy w obu regułach franciszkańskich pozostaje ten sam, ma to być diaconia, czyli służba na rzecz ludzkiej społeczności, posługa pożyteczna i korzystna, której owoce mają służyć innym braciom ${ }^{51}$. Natomiast proszenie o jałmużnę w myśli Franciszka jest jedynie środkiem pomocniczym, a Bracia Mniejsi mogą się doń uciekać, kiedy nie wystarczałoby wynagrodzenie za pracę ${ }^{52}$.

\section{6a. Contemptus mundi ze względu na Pana}

Mt 19, 21 i Mt 6, 34 od Antoniego Egipskiego pozostają wiodącymi tekstami biblijnymi, na które powoływali się mnisi rezygnujący z dóbr tego świata ze względu na eschatologiczny wybór Boga i jego spraw (por. Vita

\footnotetext{
$46 \quad$ Franciscus Assisiensis, Regula bullata 5: Pisma FK, s. 184.

47 Franciscus Assisiensis, Testamentum 20: Pisma FK, s. 216.

48 Franciscus Assisiensis, Epistola ad sanctum Antonium 2: Pisma FK, s. 268.

49 Thomas de Celano, Vita secunda 75, 3-5: FF, s. 513; ŹF, s. 619.

50 Por. Compilatio Assisiensis 62, 8: „Vade viam tuam, frater musca, quoniam tua ero-
} gasti consanguineis et vis vivere de helemosinis inter fratres” FF, 1557 (tłum. polskie: Zbiór Asyski, przekł. P. J. Nowak, ŹF, s. 1584).

51 Por. L. Iriarte, Powołanie franciszkańskie..., dz. cyt., s. 171-177.

52 Franciscus Assisiensis, Regula non bullata 9, 1-5: Pisma FK, s. 150; Franciscus Assisiensis, Regula bullata 6, 3-4: Pisma FK, s. 184; Franciscus Assisiensis, Testamentum 22: Pisma FK, s. 216. 
Antonii 1-3; 6). Dla pachomian, w myśl Ef 2, 20, dobrowolne ubóstwo jest naśladowaniem uniżonego Jezusa ${ }^{53}$, a przez praktykę stałego wyrzeczenia się świata (contemptus mundi według pierwszych cenobitów to nie pogarda dla obecnego świata, ale jego wyrzeczenie się...) mnich pachomiański jest powołany do wolności, dążąc do eschatologicznej góry Syjon, gdzie jest Bóg (por. Ga 5, 13; Jr 3, 14; Ml 1, 6) ${ }^{54}$. Idea wyrzeczenia się świata (contemptus mundi) ze względu na Boga i życie wieczne stała się następnie toposem kolejnych pism normatywnych całego późniejszego monastycyzmu chrześcijańskiego ${ }^{55}$.

\section{6b. Ubóstwo dobrowolne jako eschatologiczny znak}

Jest ono realizacją obietnicy Jezusa, danej tym Jego naśladowcom, którzy opuścili wszystko ze względu na Niego (Mt 5, 3; 19, 29). To umieszczenie swojego myślenia nie w życiu doczesnym, ale w poszukiwaniu i posiadaniu Boga. Dlatego Franciszek nazwał ubóstwo Braci Mniejszych „zadatkiem i zastawem bogactw wiecznych"56, bo „ustanowiło was, braci moich najmilszych, dziedzicami i królami królestwa niebieskiego" ${ }^{57}$.

53 Księga Horsiesiego 21: „wielką łaską [której] nam Bóg udzielił przez naszego ojca Pachomiusz: wyrzekliśmy się świata, wszelkich trosk ziemskich i przestaliśmy zabiegać o rzeczy światowe [...] Według tego krzyża żyli nasi ojcowie i budowali na fundamencie apostołów i proroków, i na nauce Ewangelii, która została oparta na kamieniu węgielnym, Panu Jezusie Chrystusie. Postępując za Nim, schodzimy ze śmiercionośnej wyniosłości do życiodajnej pokory, zamieniając bogactwo na ubóstwo, a wyszukane potrawy na proste", Pachomiana Latina, dz. cyt., s. 232-233.

54 Por. Księga Horsiesiego 47, Pachomiana Latina, dz. cyt., s. 259-260.

55 Por. J. C. Guy, La place du contemptus mundi dans le monachisme ancien, „Revue d'Ascétique et de Mystique" 41 (1965), s. 237-249.

56 Thomas de Celano, Vita secunda 55, 5: „perfectionis viam, hanc aeternam divitiarum pignus et arrham”, FF, s. 495; Thomas de Celano, Vita secunda, 70, 7: „,non praesentem sed futuram eius dotem expectat”, FF, s. 509; Thomas de Celano, Vita secunda, 74, 4: „Arrham caelestis hereditatis erubescere neqaquam regni heredibus convenit”, FF, s. 512-513.

57 Franciscus Assisiensis, Regula bullata 6, 5: „quae vos, carissimos fratres meos, heredes et reges regni caelorum instituit", Pisma FK, s. 184. 185; Clara Assisiensis, Regula 8, 4: "quae vos, carissimas sorores meas, heredes et reginas regni caelorum instituit”, Pisma FK, s. 474 . 


\section{Wnioski}

Porównując podstawowe dokumenty normatywne monastycyzmu chrześcijańskiego okresu patrystycznego i minorytyzmu okresu Franciszka z Asyżu, doszedłem do następujących wniosków:

(1.) Dla obu tradycji zakonnych przewodnią myślą biblijną o ubóstwie zakonnym jest 2 Kor 8, 9. Monastycyzm antyczny dodatkowo mocno odwołuje się do Dz 2, 44-45; 4, 32, natomiast dla Franciszka z Asyżu istotna jest jego intuicyjna lektura Mt 10, 7-19; 16, 24; 19, 21 i Łk 9, 3. 23. Obie tradycje zakonne podkreślają, że podstawowe w myśleniu o jakimkolwiek ubóstwie jest uniżenie Syna Bożego dokonane we wcieleniu. Chrześcijańskie zachowania - czy to egipskich anachoretów, czy pachomian, czy Braci Mniejszych - jedynie naśladują owo ubóstwo i pokorę Jezusa.

(2.) Wyrzeczenie się prawa własności i życie sine proprio jest wspólne dla obu tradycji zakonnych. Akt wyrzeczenia się własności indywidualnej obowiązywał zakonników obu tradycji przez całe życie i stanowił znak bycia wolnym w Bogu.

(3.) Życie doczesne i naśladowanie Chrystusa przez podjęcie życia zakonnego zarówno anachoreci egipscy, pachomianie, bazylianie, augustyńscy kanonicy, jak i Franciszek z Asyżu i pierwsi Bracia Mniejsi traktowali jako okres przejściowy i pielgrzymowanie do nieba. To idea wspólna całej tradycji Kościoła. Życie zakonne obu tradycji podkreślało szczególnie zachowanie postawy prowizoryczności w odniesieniu do środków utrzymania i zamieszkania.

(4.) Zalecenie powstrzymywania się od przyjmowania pieniędzy, gdyż deprawują i mnicha, i brata mniejszego, było w dużej mierze umotywowane chęcią zapobieżenia żądzy chciwości. Jak pokazuje historia obu tradycji, było to jednak wezwanie do pewnego ideału, gdyż pieniądze były w użyciu czy to monasterów, czy franciszkańskich klasztorów. Moim zdaniem istotę tego ascetycznego zalecenia najlepiej ujęła Klara z Asyżu, uznając za normalne posługiwanie się pieniędzmi, ale tak, aby być ubogim, także kiedy się posiada pieniądze.

(5.) Dla obu tradycji zakonnych praca jest biblijnym obowiązkiem człowieka oraz życiową koniecznością. Obie tradycje zwalczają lenistwo zakonników. Nie jest ona jednak najważniejsza w obliczu zachowania 
wewnętrznego spokoju, poszukiwania Boga. Franciszek dodatkowo podkreśla zachowanie w pracy postawy służebnej, a jałmużna jest dlań środkiem jedynie pomocniczym.

(6.) Conteptus mundi, rozumiane jako wyrzeczenie się świata ze względu na Boga, jest wspólne dla obu tradycji zakonnych, jako znak eschatologiczny tak dla braci, jak i dla innych ludzi.

Na poziomie zapisów normatywnych, w kwestii ubóstwa dobrowolnego obie tradycje zakonne są wyjątkowo zbieżne. Paradoksalnie nie powinno to dziwić. Zbieżność norm dotyczących ubóstwa dobrowolnego, kategoryzowanego przez poszczególne tradycje wynika po pierwsze z osobowego przeżywania Ewangelii przez każdego z fundatorów kolejnych zakonów. Po drugie, zapisy tego doświadczenia, uznane przez Kościół w postaci reguł i innych dokumentów normatywnych, pochodzą z okresu charyzmatycznego obu tradycji i są opisem owego egzystencjalnego doświadczenia i przeżywania tej samej Ewangelii, są kolejną urzeczywistnianą w historii Kościoła próbą powrotu do Ewangelii. Jeśli instytucjonalizacja obu tradycji zakonnych spowodowała po kolejnych 800 latach trwania tradycji materialną stabilizację (w 1200 roku dla monastycyzmu, po 2000 roku dla braci mniejszych), pozostaje aktualne pytanie o dostosowanie charyzmatu ubóstwa dobrowolnego do obecnego czasu Kościoła w świecie. Wydaje się, że pomocne w tej odpowiedzi pozostają i dziś idee założycieli zakonów zawarte w dokumentach normatywnych okresu charyzmatycznego. 


\section{Summary}

\section{Ubóstwo monastyczne a ubóstwo franciszkańskie - próba zestawienia tez normatywnych}

W artykule zestawiono wiodące idee dotyczące ubóstwa dobrowolnego dla monastycyzmu okresu patrystycznego i dla minorytów okresu św. Franciszka z Asyżu. Analiza tekstów normatywnych obu tradycji zakonnych wykazała ich zbieżność. Dotyczy ona tak przewodniej myśli biblijnej (2 Kor 8, 9 - uniżenie Syna Bożego we wcieleniu jest podstawą do naśladowania przez mnichów i zakonników ubóstwa i pokory Jezusa), jak i pozostałych tez o ubóstwie dobrowolnym: wyrzeczenia się prawa własności i życia sine proprio, życia doczesnego rozumianego jako okres pielgrzymowania do nieba, powstrzymywania się od przyjmowania pieniędzy w celu zapobieżenia chciwości, pracy jako biblijnego obowiązku i życiowej konieczności oraz wyrzeczenia się świata ze względu na Boga (contemptus mundi - znak eschatologiczny dla zakonników i świata). Zbieżność norm dotyczących ubóstwa dobrowolnego obu tradycji zakonnych wynika prawdopodobnie z osobowego przeżywania Ewangelii przez każdego z fundatorów zakonnych oraz z faktu, iż pierwotne dokumenty normatywne pochodzą z okresu charyzmatycznego obu tradycji. Normy te są zatem kolejną urzeczywistnianą w historii Kościoła próbą powrotu do Ewangelii.

Słowa kluczowe: ubóstwo dobrowolne, monastycyzm IV-VII wieku, minorytyzm XIII wieku, tezy normatywne

\section{Monastic Poverty and Franciscan Poverty - an Attempt to Juxtapose of the Normative Theses}

In this paper I focus on the leading ideas of voluntary poverty in patristic monasticism and in the Franciscan order of the times of St. Francis of Assisi. The analysis of normative theses of both orders, the patristic and the minorites traditions portray their convergence. According to 2 Corinthians 8:9- humility of Jesus in his Incarnation formed the basis of monastic life for early monasticism and for minorites as well. Christ's humility and poverty guided the spiritual life of monks of the early monasticism and Franciscan brothers. The voluntary poverty, rejection of the possession of private property, a life of "sine proprio" mean simply to consider life only as a time of pilgrimage to Heaven. The refusal of acceptance of money frees a monk from greed. Contemptus mundi i.e. contempt of the worldly concerns for the sake of God, and work as a biblical duty and necessity of life should constitute principles of the Christian existence first of all from, the eschatological point of view. The similitude of both (early monasticism and Franciscan monasticism) standards of the voluntary poverty seemed to proceed from the personal experience of the 
Bible of their founders. Both normative theses originated in the charismatic periods of both traditions. Both these norms were a practicable attempts of the Church to the evangelical sources.

Keywords: voluntary poverty, monasticism of IV-VII century,

minoritism of the XIII century, normative theses

\section{Bibliografia}

Augustinus Hipponensis, Regula ad servos Dei, a cura di L. Verheijen, Roma 2001, s. 30-48 (Nuova Biblioteca Agostiniana, vol. 7/2); przekł. pol.: Św. Augustyn, Reguła, [w:] Św. Augustyn. Pisma monastyczne, przekł. P. Nehring, Kraków 2002, s. 151-168 (Źródła Monastyczne, 27).

Basilius Magnus, Regulae fusius tractatae, Patrologia Graeca, vol. 31, ed. J. P. Migne, Paris 1857, k. 889-1052; przekł. pol.: Św. Bazyli Wielki, Pisma ascetyczne, t. 2. Reguły dłuższe. Reguły krótsze, przekł. pol. J. Naumowicz, Kraków 1995 (Źródła Monastyczne, 6).

Compilatio Assisiensis, [in:] Fontes Franciscani, t. 2. Testi, a cura di E. Manestò, S. Brufani, Assisi 1995, s. 1471-1690; tłum. polskie: Zbiór Asyski, [w:] Źródła franciszkańskie. Pisma świętego Franciszka. Źródła biograficzne świętego Franciszka. Pisma świętej Klary i źródła biograficzne. Teksty ustalające normy dla braci i sióstr od pokuty, przekł. P. J. Nowak, Kraków 2005, s. 1552-1669.

Dietz M., Wandering monks, virgins, and pilgrims ascetic travel in the mediterranean world, A.D. 300-800, University Park 2005.

Fragmenty greckie Reguły Pachomiusza, ed. T. L. Lefort, „Muséon” nr 37 (1924), s. 1-28.

Fragmenty koptyjskie Reguły Pachomiusza, Oeuvres de s. Pachôme et de ses disciplesed, ed. T. L. Lefort, Louvain 1956, s. 30-36 (Corpus Scriptorum Christianorum Orientalium 159/Copt. 23); ed. H. Bacht, „Muséon” nr 75 (1962), s. 5-18.

Gribomont J., Povertà, [w:] Dizionario degli Istitutidi Perfezione, vol. 7, a cura di G. Rocca, Roma 1983, kol. 246-248.

Guy J. C., La place du contemptus mundi dans le monachisme ancien, „Revue d'Ascétique et de Mystique" nr 41 (1965), s. 237-249.

Hardick L., Ubóstwo, [w:] Leksykon duchowości franciszkańskiej, wyd. pol. - przekł. i oprac. zbiorowe, Kraków 2006, s. 1883-1910.

Iriarte L., „Appropriatio" et "expropriatio” in doctrina sanncti Francisci, „Laurentianum" nr 11 (1970), s. 3-35.

Iriarte L., El rito de la profesión en la Orden franciscana. Apuntes históricos, „Laurentianum" nr 8 (1967), s. 178-212.

Iriarte L., La povertà nelle interpretazioni papali antiche ele conseguenze del recente decreto abrogativo delle medesime, „Studi e Ricerche Francescane” nr 9 (1980), s. 79-97.

Iriarte L., Powołanie franciszkańskie. Synteza ideałów św. Franciszka i św. Klary, przekł. S. Kafel, Kraków 1999.

Jundziłł J., Pieniądz w łacińskiej literaturze chrześcijańskiej późnego cesarstwa rzymskiego, Warszawa 1984 (Studia Antiquitatis Christianae, 3). 


\section{Dariusz Kasprzak}

Jundziłł J., Złoto i srebro jako pieniądz w łacińskiej literaturze patrystycznej okresu późnego cesarstwa rzymskiego, „Vox Patrum” nr 7 (1987) t. 12-13, s. 189-205.

Kasprzak D., Idea ubóstwa w Kościele pierwszych trzech wieków, „Analecta Cracoviensia" 42 (2010), s. 255-268.

Kasprzak D., Obrzędy przejścia podczas inicjacji monastycznej w starożytnych regułach zakonnych, [w:] Katechumenat i inicjacja chrześcijańska w Kościele starożytnym, red. P. Szczur, Lublin 2011, s. 139-173.

Kötting B., Peregrinatio religiosa. Wallfahrten in der Antike und das pilgerwesen in der alten Kirche, Münster 1950.

Księga Horsiesiego [w:] Patrologia Graeca 40, kol. 869-894; tłum. polskie: Pachomiana Latina, przekł. W. Miliszkiewicz, Kraków 1996, s. 210-271 (Źródła Monastyczne, 11).

La Règle de Saint Benoît, red. A. de Vogüé, Paris 1971-1972 (Sources Chrétiennes, 181-186); przekł. pol.: Reguła św. Benedykta, [w:] Reguła Mistrza. Reguła św. Benedykta, przekł. B. Turowicz, Kraków 2006, s. 387-503 (Źródła Monastyczne, 40).

La Règle du Maître, red. A. de Vogüé, Paris 1964 (Sources Chrétiennes,105-106); przekł. pol.: Reguła Mistrza, [w:] Reguła Mistrza. Reguła św. Benedykta, przekł. T. M. Dąbek, Kraków 2006, s. 67-371 (Źródła Monastyczne, 40).

LeclerqJ., U źródeł duchowości Zachodu. Etapy rozwoju i elementy stałe, przekł. S. Sztuka, Kraków 2009.

Légasse S., L'itineranza di Gesú e dei suoi discepoli. Storia e vangeli, [w:] Peregrinie forestieri. L'itineranza francescana, a cura di L. Padovese, Bologna 2004, s. 43-55.

Légasse S., Richesse, [w:] Supplément au Dictionnaire de la Bible, fasc. 5-6 (1982), k. 645-687.

Lozano J. M., The doctrine and practice of poverty in early monasticism, „Claretianum” nr 16 (1976), s. 5-32.

Milewski I., Pieniądz w greckiej literaturze patrystycznej IV wieku, Gdańsk 1999.

Quacquarelli A., L'educazione al lavoro. Dall'antica comunità cristiana al monacesimo primitivo, [w: Res cristiana: temi interdisciplinari do patrologia, a cura di A. Quacquarelli, Roma 1992, s. 9-22.

Raurell F., Itineranti alle origini, itineranti nel tempo: una visione biblica, [w:] Peregrini e forestieri. L'itineranza francescana, a cura di L. Padovese, Bologna 2004, s. 21-41.

Regula Sanctorum Serapionis, Macarii, Paphnutii et Alterius Macarii, Patrologia Latina, 103, ed. J. P. Migne, Paris 1851, k. 435-442; przekład: Reguła świętych ojców Serapiona, Makarego, Pafnucego i Makarego Drugiego (Reguła Czterech Ojców), [w:] Wczesne reguły monastyczne z Galii, przekł. K. Bielawski, Kraków 2007, s. 41-53 (Źródła Monastyczne, 3).

Święci Franciszek i Klara. Pisma, wyd. łac.-pol., tekst łac.: Fontes Franciscani, przekł. K. Ambrożkiewicz, Kraków-Warszawa 2002.

Thomae de Celano, Vita secunda sancti Francisci, [w:] Fontes Franciscani, 2: Testi, a cura di E. Manestò, S. Brufani, Assisi 1995, s. 443-639 (tłum. pol.: Brat Tomasz z Celano, Życiorys drugi św. Franciszka z Asyżu, [w:] Źródła franciszkańskie, przekł. C. T. Niezgoda, Kraków 2005, s. 581-730.

Tillard J. M. R., Le propos de pauvreté et l'exigence évangélique, „Nouvelle Revue Theologique" nr 100 (1978), s. 207-232, 359-372. 
Translatio Latina Regulae Sancti Pachomii, [w:] Pachomiana latina. Règle et épître de s. Théodore et "Liber" de s. Orsiesius. Texte latin de s. Jérôme, ed. A. Boon, Louvain 1932, s. 169-182 (Bibliothèque de la Revue d'histoire ecclesiastique, 7).

S. Eusebii Hieronymi Stridonensis Presbyteri, Translatio Latina Regulae Sancti Pachomii, Patrologia Latina, 23, ed. J. P. Migne, Paris 1883, k. 65-92; tłum. pol.: Św. Hieronim ze Strydonu, Reguła św. Pachomiusza, [w:] Pachomiana Latina, przekł. A. Bober, Kraków 1996, s. 123-172 (Źródła Monastyczne, 11).

Wipszycka E., Drugi dar Nilu, czyli o mnichach i klasztorach w późnoantycznym Egipcie, Kraków 2014. 